\title{
PENGARUH MODEL PEMBELAJARAN PBM TEHADAP HASIL BELAJAR PENDIDIKAN PANCASILA dan KEWARGANEGARAAN KELAS XI SMA SWASTA AEK NABARA KABUPATEN LABUHANBATU TAHUN AJARAN 2016/2017
}

\author{
Eva Perawati Lubis \\ Program Studi Pendidikan Pancasila dan Kewarganegaraan, STKIP Labuhanbatu \\ Yayasan Universitas Labuhanbatu
}

\begin{abstract}
ABSTRAK
LUBIS EVA PERAWATI. 013.043.00.021 "Pengaruh Model Pembelajaran PBM Terhadap Hasil Belajar Pendidikan Pancasila dan Kewarganegaraan Kelas XI SMA Swasta Aek Nabara Kabupaten Labuhanbatu Tahun Ajaran 2016/2017". Skripsi, Rantau prapat: Sekolah Tinggi Keguruan dan Ilmu Pendidikan (SKTIP) Labuhanbatu

Penelitian ini menggunakan Quasi Eksperimen. Desain ini dipilih untuk menganalisis pengaruh yang terjadi antara variabel X ( Indevenden ) terhadap variabel Y (Dependen ) berdasarkan perbedaan hasil belajar siswa yang diajarkan pada kelas eksperimen yang menggunakan Model Pembelajaran Berbasis Masalah dan siswa kelas kontrol yang menggunakan pembelajaran secara Langsung. Populasi dalam penelitian ini adalah seluruh siswa kelas XI ips dan kelas XI ipa II SMA Swasta Aek Nabara yang berjumlah 40 orang. Siswa pada kelas Eksperimen ( XI ips ) diberikan pembelajaran dengan menggunakan Model pembelajaran Berbasis Masalah, terlebih dahulu dilakukan pretest dan nilai rata - rata pretest sebesar 38,75 dengan standar deviasi 8,9. Sedangkan pada kelas kontrol ( XI ipa ) yang tanpa diberikan perlakuan berupa Model sebelum perlakuan juga diberikan pretest dengan nilai rata - rata sebesar 40,75 dengan standar deviasi sebesar 8,5. Data postest siswa pada kelas eksperimen ( XI ips ) diberikan model pembelajaran berbasis masalah, dimana menunjukkan dengan nilai rata - rata postest sebesar 40,05 dengan standar deviasi 7,7. Sedangkan pada kelas kontrol ( XI ipa) yang diberikan tanpa model dengan nilai rata - rata 40,05 dengan standar deviasi 8,5. Berdasarkan perolehan nilai rata - rata postest pada kedua kelompok siswa tersebut setelah diberikan perlakuan yang berbeda antara kelas eksperimen dan kelas kontrol terdapat perbedaan rata - rata nilai hasil belajar yang signifikan. Hal tersebut juga dibuktikan dengan hasil pengujian hipotesis yaitu dengan perolehan nilai Thitung $=$ $4,559 \geq$ Ttabel. Siswa kelas eksperimen yang diberikan model pembelajaran berbasis masalah memiliki pengaruh yang signifikan terhadap hasil belajar pada materi Hubungan Internasional.
\end{abstract}

Kata Kunci : Model, pembelajar berbasis Masalah, Hasil Belajar, Materi Hubungan Internasional 


\section{Kajian:}

Pembelajaran PPKn

\section{PENDAHULUAN}

Pendidikan adalah usaha sadar dan terencana untuk mengembangkan potensi sumber daya manusia melalui kegiatan pembelajaran yang bertujuan untuk membantu peserta didik dalam pengembangan semua potensi serta karakteristik pribadinya menuju ke arah yang lebih baik. Keberhasilan dalam pencapaian suatu tujuan pendidikan sangat ditentukan oleh proses pembelajaran yang sedang dilaksanakan oleh peserta didik. Dengan adanya proses pembelajaran ini diharapkan peserta didik dapat mpeningkatkan aspek pengetahuan, sikap maupun keterampilannya.

Keberhasilan belajar mengajar merupakan hal yang sangat diharapkan pendidik dalam melaksanakan tugasnya, namun pendidik bukanlah satu-satunya faktor yang mempengaruhi keberhasilan belajar tersebut. Faktor tujuan, peserta didik, kegiatan pengajaran, alat evaluasi, bahan evaluasi dan suasana evaluasi merupakan faktor-faktor yang dapat menentukan keberhasilan suatu proses pembelajaran.

Proses belajar mengajar yang baik dan benar akan sangat menentukan dari keberhasilan pendidikan. Belajar itu sendiri mempunyai pengertian aktivitas atau kegiatan seseorang sehingga menyebabkan adanya menuju tingkah laku yang lebih baik. Belajar mempunyai pengaruh yang sangat besar dalam membentuk karakter seseorang. Sebelum proses kegiatan belajar mengajar itu dilaksanakan pendidik secara sadar akan merencanakan pembelajaran secara sistematis dengan selalu memanfaatkan sarana dan prasarana yang ada guna kepentingan pembelajaran. Hal ini bertujuan agar pembelajaran yang akan 


\section{Kajian:}

\section{Pembelajoran PPKn}

dilaksanakan dapat berjalan sesuai dengan apa yang diharapkan dan dapat mencapai tujuan pembelajaran yang ingin dicapai.

Salah satu masalah yang dihadapi dunia pendidikan adalah pembelajaran masih didominasi oleh pendidik, sehingga aktivitas peserta didik dalam proses belajar mengajar di kelas menjadi pasif. Akibatnya peserta didik menjadi acuh terhadap apa yang sedang dijelaskan pendidik di depan kelas. Peserta didik lebih senang bermain atau berbicara sendiri dengan teman sebangkunya. Dalam proses pembelajaran di kelas peserta didik masih disuruh untuk menghafal, mengingat serta mengumpulkan informasi tanpa dituntut untuk memahami apa yang didapatkan dari informasinya tersebut. Hal ini mengakibatkan kegiatan pembelajaran PPKn masih bersifat monoton dan cenderung kurang menarik, sehingga setiap pelajaran berlangsung peserta didik menjadi kurang tertarik dan minat belajar menjadi hilang dalam mengikuti kegiatan belajar mengajar.

$$
\text { Mata pelajaran Pendidikan }
$$

Pancasila dan Kewarganegaraan adalah mata pelajaran yang sangat penting bagi siswa. Fokus dari Pendidikan Pancasila dan Kewarganegaraan ini adalah pembentukan warganegara yang mampu memahami serta mampu melaksanakan hak-hak dan kewajibannya untuk menjadi warganegara Indonesia yang cerdas, taat pada hukum sesuai dengan yang diamanatkan dalam Undang- Undang Dasar 1945. Pendidik harus mempunyai cara atau strategi pembelajaran yang tepat, supaya pembelajaran dapat fokus terhadap peserta didik dan suasana di kelas menjadi menyenangkan serta tidak pasif. Hal ini dimaksudkan supaya peserta didik menjadi 


\section{Kajian:}

Pembelajaran PPKn

aktif berfikir, aktif mengeluarkan

pendapatnya. Sedangkan pendidik dituntut

untuk dapat memanfaatkan berbagai

macam model pembelajaran yang ada

dengan baik. Dari uraian singkat diatas,

penulis memilih model pembelajaran

berbasis masalah atau yang biasa kita sebut

juga dengan "Problem Based Learning”.

Pembelajaran Berbasis Masalah

merupakan suatu pendekatan pembelajaran yang menggunakan masalah dunia nyata sebagai suatu konteks bagi siswa untuk merangsang berfikir tingkat tinggi siswa dalam situasi yang berorientasi pada masalah dunia nyata.Lingkungan belajar yang harus disiapkan dalam Pembelajaran Berbasis Masalah adalah lingkungan belajar yang terbuka dan menekankan pada peran siswa aktif. Seluruh proses membantu siswa untuk menjadi mandiri dan otonom yang percaya pada keterampilan intelektual mereka sendiri.

Lingkungan belajar menekankan pada peran sentral peserta didik bukan pada pendidik. Pembelajaran Berbasis Masalah dapat dilakukan dengan cara mencari permasalahan yang ada di lingkungan sekitar, dan peran guru hanya menjadi fasilitator dalam menyelesaikan masalah yang ditemukan.

Dalam model pembelajaran berbasis masalah, masalah dapat berasal dari peserta didik atau mungkin juga diberikan oleh pendidik. Peserta didik harus terpusat pada masalah yang sedang dibahas, dengan seperti itu maka peserta didik dengan sendirinya akan belajar mengenai teori serta metode ilmiah untuk dapat memecahkan masalah yang sedang dibahas dengan baik dan benar. Pemecahan masalah dalam pembelajaran ini harus sesuai dengan langkahlangkah 


\section{Kajian:}

Pembelajoron PPKn

metode ilmiah. Hal ini mengakibatkan efek positif pada peserta didik, yakni peserta didik memecahkan masalah secara sistematis dan terencana. Pemilihan masalah yang akan disajikan dalam proses pembelajaran harus tepat. Hal ini mempunyai pengertian bahwa pemilihan masalah yang cakupannya

kurang luas, masalah yang tidak sesuai dengan materi yang sedang dipelajari akan menghambat tujuan pembelajaran yang ingin dicapai. Oleh karena itu, pendampingan pendidik dalam hal ini sangat besar tanggung jawabnya. Pendidik tidak diperkenankan mengintervensi terhadap masalah, akan tetapi pendidik lebih memfokuskan melalui pertanyaanpertanyaan agar peserta didik merefleksi lebih dalam tentang masalah yang dipilih.

\section{METODE PENELITIAN}

\section{Lokasi Penelitian}

Penelitian ini dilaksanakan diSMA Swasta Aek Nabara Kabupaten Labuhanbatu. Alasan peneliti mengambil lokasi diSMA Swasta Aek Nabara, untuk mengetahui adanya pengaruh model pembelajaran berbasis masalah terhadap hasil belajar pendidikan kewarganegaraan di kelas XI IPS

\section{Pembahasan Hasil Penelitian}

Siswa pada kelas Ekperimen ( XI ips ) diberikan pembelajaran dengan menggunakan Model Pembelajaran Berbasis Masalah, terlebih dahulu di lakukan pretest dan nilai rata - rata pretest sebesar 38,75 dengan standar deviasi 8,9. Sedangkan pada kelas kontrol ( XI ipa ) yang tanpa diberi perlakuan berupa Model sebelum perlakuan juga diberi pretset dengan nilai rata -rata pretest sebesar 40,75 


\section{Kajian:}

\section{Pembelajoran PPKn}

dengan standar deviasi 8,5.

Data postest siswa pada kelas eksperimen ( XI ips ) diberikan Model Pembelajaran Berbasis Masalah, dimana menunjukkan dengan nilai rata - rata postest sebesar 40,05 dengan standar deviasi 7,7. Sedangkan pada kelas kontrol (XI ipa ) yang diberi perlakuan tanpa Model dengan nilai rata - rata 40,05 dengan standar deviasi 8,5.

Berdasarkan perolehan nilai rata rata postest pada kedua kelompok siswa tersebut, setelah diberikan perlakuan yang berbeda antara kelas eksperimen dan kelas kontrol terdapat perbedaan rata - rata nilai hasil belajar yang signifikan. Hal tersebut juga dibuktikan dengan hasil pengujian hipotesis yaitu dengan perolehan nilai Thitung $=4,559 \geq \mathrm{T}$ tabel.

Siswa kelas eksperimen yang diberikan Model Pembelajaran Berbasis

Masalah memiliki pengaruh yang signifikan terhadap hasil belajar pada materi Hubungan Internasional.

\section{Kesimpulan}

Berdasarkan hasil penelitian dan pembahasan mengenai perbedaan hasil belajar dengan menggunakan model pembelajaran berbasis masalah, bab sebelumnya, dapat diambil kesimpulan sebagaiberikut.

Hasil belajar dengan model pembelajaran berbasis masalah bagikelas XI

SMASwasta

AekNabarasangatberpengaruhdalammeningk atkanh asilbelajar.

\section{Implikasi}

Berdasarkan hasil penelitian yang telah dilaksanakan oleh peneliti, bahwa terdapat hasil belajar siswa dengan menggunakan model pembelajaran 


\section{Kajian:}

\section{Pembelajoran PPKn}

berbasis masalah. Hal ini menunjukkan secara teoritis hasil penelitianini dapat digunakan sebagai salah satu acuan untuk memilih pembelajaran pada mata pelajaran PKn yang sesuai dengan tujuan pembelajaran, materi pelajaran, sarana dan prasarana pembelajaran serta karakteristik siswa.

\section{Keterbatasan Penelitian}

Keterbatasan penelitian yang dialami di kelas XI SMA AekNabarasebagaiberikut:

1. Pembelajaran menggunakan model pembelajaran berbasis masalah memerlukan waktu yang cukup lama sedangkan guru harus menyesuaikan dengan alokasi waktu yang tertera dalam RPP.

2. Penelitian ini hanya dilakukan selama 4 kali pertemuan pada setiap model yang digunakan yaitu model pembelajaran berbasis masalah, sehingga untuk mendapatkan perbedaaan hasil belajar lebih maksimal dengan penerapan kedua model tersebut membutuhkan waktu penelitian lebih lama.

3. Keterbatasan guru dalam membimbing siswa ketika diskusi kelompok karena kadang ada siswa yang sulit diatur untuk berpendapat didalam kelompoknya.

\section{Saran}

Berdasarkan kesimpulan, implikasi dan keterbatasan masalah pada penelitian yang dilaksanakan di SMA Swasta AekNabara yang sudah dipaparkan oleh penulis, maka peneliti memberikan beberapa saran sebagai berikut.

\section{Bagi Guru}

a. Guru dapat mencoba menggunakan model pembelajaran berbasis masalah pada pembelajaran PKn untuk 


\section{Kajian:}

Pembelajoran PPKn

diterapkan pada pelajaran lain yang

memiliki. Tujuannya adalah agar siswa

memiliki kesiapan, rasa tanggung

jawab, serta termotivasi sehingga dapat

meningkatkan hasil belajar siswa.

b. Guru harus mampu mengalokasikan waktu dengan sebaik-baiknya ketika menggunakan metode sehingga model pembelajaran berbasis masalah kegiatan dapat diterapkan sesuai aturan.

\section{Bagi Siswa}

a. Siswa lebih berani mengemukakan pendapatnya pada saat diskusi kelompok berlangsung. Siswa berani bertanya kepada guru apabila masih ada materi pelajaran yang belum jelas dan belum dipahami agar siswa dapat memahami dan mendapatkan hasil belajar yang optimal.

b. Siswa diharapkan selalu kreatif dalam menyelesaikan masalah selama mengikuti kegiatan pembelajaran, untuk berpendapat , bertukar pikiran dalam

diskusi berlangsung.

\section{Bagi Sekolah}

a. Sekolah diharapkan dapat memberikan dukungan penuh terhadap guru untuk mengembangkan berbagai variasi metode pembelajaran yang diterapkandidalam kelas.

b. Sekolah diharapkan menyediakan sarana dan prasarana yang diperlukandalam segala kegiatan untuk menunjang kreatifitas guru dan siswa.

\section{Bagi peneliti lain}

a. Bagi peneliti selanjutnya diharapkan dapat memperluas pokok bahasan agar dapat memperoleh hasil penelitian yang lebih baik. 


\section{Kajian:}

\section{Pembelajoran PPKn}

\section{DAFTAR PUSTAKA}

Cholisis. ( 2004 ). Pendidikan Kewarganegaraan Yogyakarta UNY press.

Cholisis. ( 2004 ). Perspektif pendidikan pancasila dan kewarganegaraan.Bandu Kaifa.

Dimyati dan Mudjiono. (2009).Belajar dan Pembelajaran.Jakarta PT Rineka Cipta

Darsono. ( $\quad 2000 \quad$ ).Belajar

Pembelajaran.Semarang IKIP Press.

Hamalik,Oemar.( 2005 ).Perencanaan pengajaran berdasarkan pendekatan System. Jakarta PT Bumi Aksara.

Ibrahim,M.dan Nur,M. ( 2002 ).Pembelajaran berbasis masalah. Surabaya UNESA University press.

Kaelan. ( 2010 ).Metode penelitian kualitatif bidang filsafat.Yogyakarta Paradigma.

Meleong,Lexy j. ( 2000 ). Metode penelitian kualitatif. Bandung PT Remaja Rosdakarya.

Nana Syaodih Sukmadnata. ( 2009 ).Metode pendidikan.Bandung PT Remaja Rosdakarya.

Rusman. ( 2010 ).Model - model Pembelajaran mengembangkan profesionalisme Guru. Jakarta PT

Raja Grafindo Persada.

Syaiful Bahri Djamarah,Aswan Zain. ( 2002
).Strategi belajar

mengajar. Jakarta

PT.Rineka Cipta.

Sugiyanto.(2010).Model $\quad-\quad$ model pembelajaran Inovatif. Surakarta Yuma Pustaka.

Sugiyono.(2009).Metode penelitian kuantitatif dan $R \quad \& \quad D$.Bandung Alfabeta

Sumantri, Mulyani, dkk ( 1999 ) Strategi belajar mengajar. Jakarta Departemen

Pendidikan dan kebudayaan.Direktorat Jendral pendidikan tinggi.

Suparno.(1997).Filsafat

konstruktivisme dalam pendidikan.Yogyakarta Kanisius

Soemantri. ( 2001 ).Mendesain model pembelajaran pendidikan. Bandung Remaja

Rosda Karya.

Tritanto. ( 2009 ). Mendesain Model pembelajaran Inovatif Progresif. Jakarta

Kencana Prenada Group.

Tritanto. ( 2010 ).Mendesain Model pembelajaran Inovatif Progresif. Jakarta Kencana Prenada Group. 
ISSN: 2460-611

\section{Kajian:}

Pembelajoran PPKn

Winarno.( 2013 ).Paradigma Baru

pendidikan kewarganegaraan. jakarta.

http://digilib.uinsby.ac.id./8742/5/b

ab2.pdf. 